\title{
Compact Spinning in Cotton-based Core-spun Yarn: A Review
}

\author{
Md Ehsanur Rashid, \\ Bangladesh University of Textiles, Bangladesh. \\ Raihan UI Haque, \\ Bangladesh University of Textiles, Bangladesh. \\ Md. Rubel Khan, Assistant Professor, \\ Department of Yarn Engineering, \\ Bangladesh University of Textiles, Bangladesh
}

Doi:10.19044/esj.2021.v17n37p287

Submitted: 18 June 2020

Accepted: 12 October 2021

Published: 31 October 2021
Copyright 2021 Author(s)

Under Creative Commons BY-NC-ND 4.0 OPEN ACCESS

Cite As:

Rashid E., Ul Haque R. \& Khan R. (2021). Compact Spinning in Cotton-based Core-spun Yarn: A Review. European Scientific Journal, ESJ, 17(37), 287.

https://doi.org/10.19044/esj.2021.v17n37p287

\begin{abstract}
In today's world, textile outfits are chosen not only for their functional properties but also for their comfort. As cotton is synonymous with comfort in textile industries, cotton-based core-spun yarn is becoming increasingly popular day by day, where the core element satisfies the functional properties and the cotton sheath provides a good hand feel and comfort. At the beginning of the twenty-first century, researchers developed a new spinning modification known as the compact spinning system to improve yarn quality. In cottonbased compact core-spun yarn, reduced hairiness, unevenness (U\%), thick place, thin place, neps, and increased strength are achieved. This will also lead to significant abrasion and piling resistance, higher air permeability, lower thermal resistance, and higher Relative Water Vapor Permeability (RWVP). This review paper illustrates the advantages of spinning cotton-based corespun yarn in the compact spinning system.
\end{abstract}

Mots clés: Cotton, Comfort, Core-Spun Yarn, Compact Spinning, Hairiness, Spinning Triangle 


\section{Introduction}

Core spun yarns have a structure in which one of the constituents, usually a mono or multifilament synthetic filament, is shielded by another part, the staple fiber sheath (Alsaid Ahmed Almetwally, 2014; Babaarslan, 2001; H. Helali, Babay, 2012; Kumar, 2014; Yang, 2009). The majority of core-spun yarns are made on ring and friction spinning machines. Ring spinning has been prioritized over other spinning technologies, howbeit friction spinning has also been portrayed as quite effective, despite the major drawbacks of falsetwisted core material and poor core-sheath spillage resistance (Harper, 1986; H. J. Kim, Yang, 2009; Ruppenicker, 1989). The primary aspect of using core-spun yarn is to reap the benefits from each of its components' features. The process of manufacturing core-spun yarn is very straightforward, and core and cover materials can be chosen from a variety of fibers with predetermined end uses.

Clothing comfort is characterized as a comfortable state arising from physiological, psychological, and physical harmony between a human being and the environment, which is a fundamental and universal need for consumers (Raj \& Sreenivasan, 2009). Clothing comfort is usually divided into three groups in the literature: (a) aesthetic comfort, (b) thermophysiological comfort, and (c) tactile comfort (Yoon, 1984). Customer tastes are influenced by subjective emotions and fashion trends, which affect aesthetic appeal or psychological comfort. Thermo-physiological comfort, on the other hand, refers to the fabric's ability to sustain thermal equilibrium between the human body and the environment. The mechanical contact between the clothing material and the human body is connected to tactile comfort. The fabric tactile properties have long been assessed using a subjective approach known as fabric handle (Kawabata \& Niwa, 1989, 1991), but a recent study shows that friction plays a significant role in the hand of fabrics (Ramkumar, 2000). Hence, the true quality of apparel fabrics will be dictated by the Hand value combined with the weighed transport properties.

Cotton is undoubtedly responsible for moisture absorption, heat resistance, air permeability (H. J. Kim, Yang, 2009; Ruppenicker, 1989) as well as hairiness, unevenness, and other characteristics when a mixture of cotton and any filament is used (Erez \& Çelik, 2014; Hua, 2018). On the other hand, the filament has strong tensile properties (Matsumoto, 1990; Merati, 2012). Thermal behavior, moisture vapor interaction, surface characteristics, and other fabric characteristics all affect clothing comfort (B. K. Behera, 1997; A. Das, 2007; B. Das, 2007, 2009; Oğulata, 2007).

So, if we can improve the moisture absorption, heat resistance, air permeability, hairiness, unevenness, and other characteristics of cotton by different spinning techniques, we can improve the comfort of clothing. 


\section{Discussion}

Core yarns are becoming increasingly popular as a result of the combination of two distinct material properties in a single yarn. Thousands of studies on core-spun yarn and fabric manufactured from it can be found in the literature, demonstrating its significance in the textile industry. Researchers have used lycra, dorlastan, spandex, T400 (elastic fiber), and Elastane to enhance the stretchability and elongation property (Adeli, 2011; Bedez Ute, 2019; H. Helali, Babay Dhouib, 2012; Kadoğlu, 2016; Kakvan, 2007; Su, 2020; Yanhong, 2019), polyester, nylon, and kevlar to improve rigidity and high strength (Ferreira, 2004; Gharehaghaji, 2007; M. Miao, 2010; Shanbeh, 2011), and Polyvinyl acetate (PVA) to produce hollow yarn because it is soluble in boiling water (A. Das, 2004; Javazmi, 2014), copper, stainless steel, and carbon fiber (CF) to generate conductive yarn and fabric (Lou, 2005; Yuan, 2019; Zaidi, 2018). Researchers employed several natural fibers (Chakraborty \& Chatterjee, 1994; Dang, 2008; Doran \& Sahin, 2020) such as cotton, wool, and silk to take advantage of their inherent properties. For example, wool and silk are good thermal insulators, whereas cotton is breathable, absorbent, and lightweight, increasing comfort. Different manmade synthetic fibers, such as nylon, polyester, polypropylene, and acrylic, are also used by researchers (Bar , 2018; du , 2015; Menghe Miao, 1996; Pourahmad \& Johari, 2009) for their quick-dry ability, durability, colorfastness, and strength. When it comes to the comfort criteria of fabrics, cotton outperforms all other fibers. After over four decades of experimenting with synthetics, most people would agree that there is no comparison to cotton in terms of comfort, even though synthetics may be more long-lasting and have a better aesthetic look. Cotton, as a natural fiber, has basic fiber properties that are innately heterogeneous. It is the most prevalent natural fiber used in the textile industry, so using cotton as a sheath material in the core-spun yarn is becoming more prominent. Furthermore, because of its good core coverage, $100 \%$ cotton sheath provides excellent aesthetics, absorbency, and thus comfort, as well as crucial substrate properties, particularly in the application of special chemical finishes and adhesives (Sawhney \& Ruppenicker, 1997). Cotton-based core-spun yarn can be classified into three categories such as (a) cotton-based elastane core-spun yarn (b) cotton-based rigid core-spun yarn (c) cotton-based conductive core-spun yarn.

Lycra, Dorlastan, Spandex, T400 (elastic fiber), and other elastic synthetic fibers are used in cotton-based core-spun yarn (Akankwasa, 2016; Bouhjar , 2012; Choi \& Kim, 2004; H. Helali, Babay Dhouib, 2012; Houda Helali, 2013; Jaouachi, 2011) (Gorjanc \& Bizjak, 2014; Sinha, 2017). These elastic fibers have such a polyurethane polymer chain that allows them to stretch between 400 and $800 \%$ Since elastic synthetic fibers are used as the core element, the fabric produced from these yarns possesses high elasticity 
and elastic recovery (Gazi Ortlek \& Ulku, 2007; H, 2013; Wang, 2016), as well as dimension stability (Ertaş, 2016; B. Qadir, 2014; Sitotaw, 2018), which lessens bagging deformation in fabrics (Herath \& Kang, 2008; Hyun, 1997; Jabbar, 2020). Cotton elastane core yarn fabrics are becoming more common in denim fabric (Stretch, Super stretch) thanks to the above-mentioned properties (Realff, 2015; Şengöz, 2004). Cotton elastane yarns are used to create knitted (Ertaş, 2016; M. B. Qadir, 2020) (Single Jersy, Rib, Interlock), and woven (Gokarneshan \& Thangamani, 2010; Oparin, 2010; Sitotaw, 2018) fabrics. Leisurewear, hosiery, and underwear are produced from these fabrics (Kaynak, 2017; B. Qadir, 2014).

Nylon, Polyester, PVA, Dyneema, and other rigid synthetic fibers are used in cotton-based core-spun yarn (Jeddi, 1997; H. J. Kim, Kim, 2009; Merati, 1998; Merati \& Okamura, 2001, 2003; Naeem, 2019; Sawhney \& Ruppenicker, 1997). These rigid fibers are used to enhance the yarn's strength, while the cotton sheath provides excellent comfort (Harper, 1986; Pramanik \& Patil, 2009; Radhakrishnaiah \& Sawhney, 1996; Ruppenicker, 1989; Sawhney, 1989; Sawhney, Robert, 1992). These yarns are now used to make non-stretch denim (Ertaş, 2016; Sarığlu \& Babaarslan, 2017), knitted (su , 2007), and woven fabrics (Harper \& Ruppenicker, 1987; Radhakrishnaiah, 1993; Sawhney, Harper, Robert, 1991; Sawhney, Harper, Ruppenicker, 1991). These types of yarn are used to produce sewing threads and protective cloths (Military fabric, Military Tent, Abrasive drill fabrics) that demand substantial strength to function accurately (Sawhney, Ruppenicker, 1992). US Army Tents are built of cotton-based Dyneema core-spun yarn fabrics (Sawhney \& Ruppenicker, 1997). High abrasive fabrics that are industrial abrasive cloth, are heavy duty and used as foundation cloth in industries (Sawhney \& Ruppenicker, 1997).

Cotton-based electrically conductive yarns can be produced using conductive elements as a core, such as stainless steel (Perumalraj, 2009; Perumalraj \& Dasaradan, 2009, 2010; Ramachandran \& Vigneswaran, 2009), copper (Yu, 2017), and so on. Another method is to treat textiles with conductive materials including carbon nanotube (CNT) (Sun, 2016; Wang, 2016). Because of the better characteristics of conductive polymers, thermal expansion, density, and chemical (corrosion and oxidation resistance) properties, these textiles are used to shield and restrict Electromagnetic Interference (EMI) and Electrostatic Discharge (ESD) (Chen \& Tsai, 1989; Hoeft \& Tokarsky, 2000; Perumalraj \& Dasaradan, 2009). These electrically conductive yarns are used to build knitted and woven fabrics that are used in military, medical, telecommunication, and health care apparel, as well as power cloth (Ramachandran \& Vigneswaran, 2009; Yu, 2017). These fabrics are also used to protect household appliances, FM/AM radio broadcast sets, 
wireless phones, cellular phones, computers, buildings, secret rooms, and a variety of electronic equipment (Perumalraj, 2009).

All of these cotton-based core-spun yarns and fabrics are primarily designed for functional purposes with little regard for hand feel and comfort, as well as how the consumer feels when using those products manufactured from them. Since the beginning of the twenty-first century, researchers have been emphasizing comfort properties alongside functional properties, and they have been attempting to develop new techniques or methods to enhance the comfortability of fabric, as buyers and consumers have prioritized good comfort and hand feel property. One significant advancement is known as compact spinning. Compact spinning is a ring spinning phenomenon that reduces the spinning triangle to minimize yarn hairiness and help boost yarn tenacity (Fu, 2021; Jiang, 2012; Krifa \& Ethridge, 2006; Regar, 2017; T. Siddiqua, M. A. Reza, and H. Altaf, 2019). The primary distinction in the compact spinning system is that the drawing section of the compact spinning machine ends with a condensation zone, which facilitates the minimization of the spinning triangle (Abou-Nassif, 2014; Basal \& Oxenham, 2006; Beceren \& Nergis, 2008; Elite \& Gmbh, 2019; Jiang, 2012; Liu, 2019; Loganathan, n.d.; M. A. Shahid, M. D. Hossain, M. N. U. Hasan, and M. A. Islam, 2014; Ma, 2012; Messiry, 2013; Ramakrishnan, 2006; Taylor, Liu, 2014; Yilmaz, 2013). Yarn tenacity, number of twists, hairiness, Imperfection Index (IPI), Yarn diameter, Packing density (Gokarneshan, 2005; Raja, 2012; Taylor, Raja, 2014), etc. are affected by compact spinning (Tyagi, Bhowmick, 2010).

\section{Advantages of Compact Spinning}

\section{Low Twist, Higher Yarn Strength, Higher Production Rate}

Table 1 demonstrates that introducing a low amount of twist results in an increased yarn strength. Compact spinning eliminates the spinning triangle, enabling more short fibers to participate in yarn construction, leading to higher yarn strength and lower twist insertion as a result the output rate increases ( $F$. Göktepe, D. Yilmaz, and Ö. Göktepe, 2015; Józkowicz \& Drobina, 2010; Özdil, 2005; T. N. Shaikh, R. Radadiya, and A. Rawal, 2017) as a low twist is applied (Abou-Nassif, 2014; Ahmad, 2009; El-Sayed \& Sanad, 2007, 2010; Taylor, 2012; Wu, 2009).

\section{Reduced Hairiness, Unevenness, Thin Place, Thick Place}

Table 1 illustrates that compact yarn shows a downward trend compared to ring yarn in hairiness, unevenness, thin place, thick place. The spinning triangle is eliminated in compact spinning, and as a result, protruding short fibers participate in forming yarn that does not engage in the conventional ring system. And because of that, hairiness, unevenness ( U\%, $\mathrm{CV} \%$ ), thin place, thick place, and neps are significantly lowered when 
compared to conventional ring yarn (Alsaid Ahmed Almetwally, 2015; Dash, 2002; H. A. Kim \& Kim, 2018; M. Krifa, E. Hequest, and D. Ethridge, 2002; Mamun, 2017; Murugan \& Shenmugam, 2021; Nikolić, 2003; Özgüney, 2008; P. Çelik, and H. Kadoğlu, 2004; Suzan, 2011; Uddin \& Jalil, 2015; Zou, 2011).

\begin{tabular}{|c|c|c|c|c|}
\hline & 30 & 40 & 30 & 40 \\
& $\mathrm{Ne}$ & $\mathrm{Ne}$ & $\mathrm{Ne}$ & $\mathrm{Ne}$ \\
\hline Twist, turns/m & 820 & 924 & 750 & 846 \\
\hline Tenacity, cN/tex & $\begin{array}{c}17.3 \\
1\end{array}$ & $\begin{array}{c}16.0 \\
8\end{array}$ & $\begin{array}{c}20.5 \\
4\end{array}$ & 18.81 \\
\hline Breaking elongation, \% & 4.68 & 4.6 & $\begin{array}{c}4.8 \\
2\end{array}$ & 4.92 \\
\hline Hairiness (Uster), H & 5.79 & 5.7 & $\begin{array}{c}5.0 \\
4\end{array}$ & 4.36 \\
\hline Unevenness (Uster), \% U & 9.15 & 9.97 & 8.9 & 9.73 \\
\hline Thin places (50\%), km & 0 & 1.2 & 0 & 1 \\
& & & & 2 \\
\hline Thick places (+ 50 \%), km & 7 & 9.4 & 4 & 10.4 \\
\hline
\end{tabular}

Table 1. Properties of different count's yarn (Akaydin, 2009).

\section{Better Abrasion and Pilling Performance}

Pilling and Abrasion curve in Figure1 indicates better performance for compact fabric. The compact fabric has better abrasion resistance and pilling resistance because of the yarn's low hairiness and compact structure (Akaydin \& Can, 2010; Barzoki, 2017; G. Manonmani, C. Vigneswaran, K. Chandrasekaran, and T. Ramachandran, 2013; Jackowski \& Cyniak, 2004; Manonmani, 2010; Omeroglu \& Ulku, 2007; Özdil, 2005; Özgüney, 2008; Ozturk \& Nergis, 2008; Sowrov \& Ahmed, 2014; Tyagi, Bhowmick, 2010; Wan, 2014).
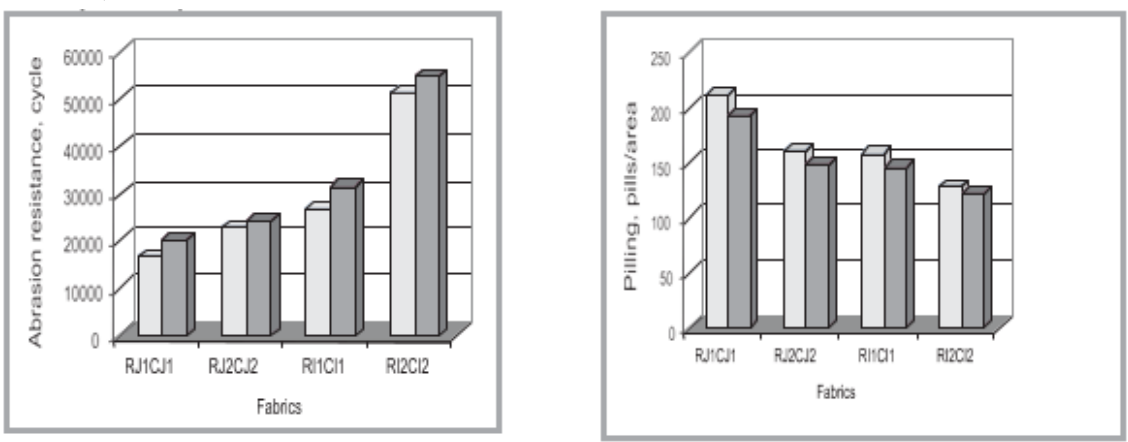

RJ1, RJ2, RI1, RI2- Fabric Produced from Ring Yarn CJ1, CJ2, CI1, CI2 - Fabric Produced from Ring Yarn

Figure 1. Pilling and Abrasion Resistance of compact fabric (Akaydin \& Can, 2010) 


\section{Higher Air Permeability}

Fabric made from compact yarn has greater air permeability (Ali \& Nassif, 2017; Alsaid A Almetwally \& Salem, 2010; Taylor, 2011), Figure 2 shows that the compact fabric has greater air permeability than the ring. This is largely attributable to the compactness of the yarn, which decreases the yarn diameter (Altas \& Kadoğlu, 2012; Dash, 2002; Ishtiaque, 2009; Yilmaz, 2007) and yarn hairiness (Altas \& Kadoğlu, 2012; Bijoya Kumar Behera, 2020; Divya, 2016; Elmogahzy, 2006; Eng, 2013; Haleem \& Wang, 2015; Hasan, 2016; Tyagi, Bhattacharyya, 2010a; Z. Xia, X. Wang, W. Ye, and W. Xu, 2015), resulting in a higher porosity of the fabric in compact fabric.

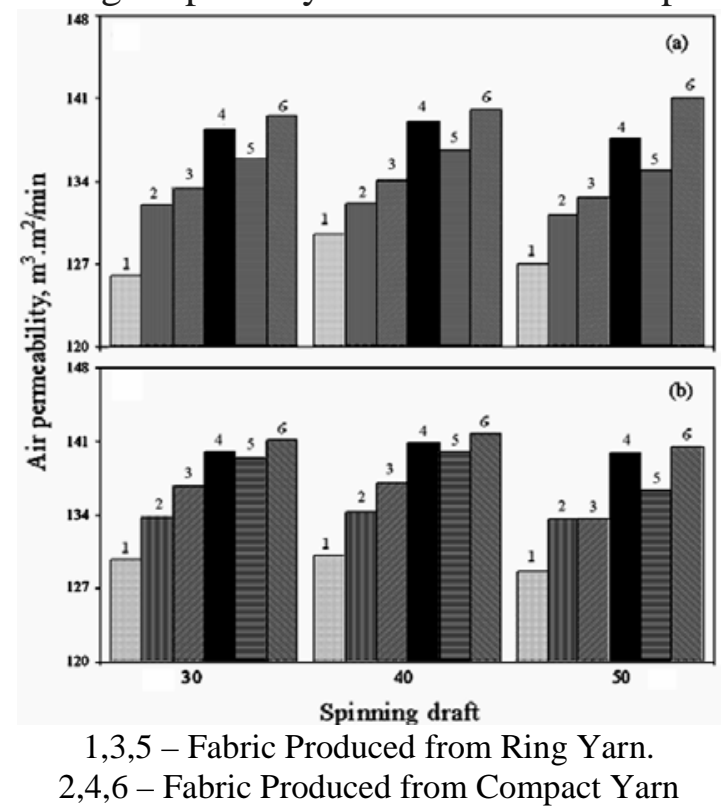

Figure 2. Air permeability (Tyagi, Bhattacharyya, 2010b)

Good Thermal Properties (Relative Water Vapor Permeability and Thermal Resistance) 

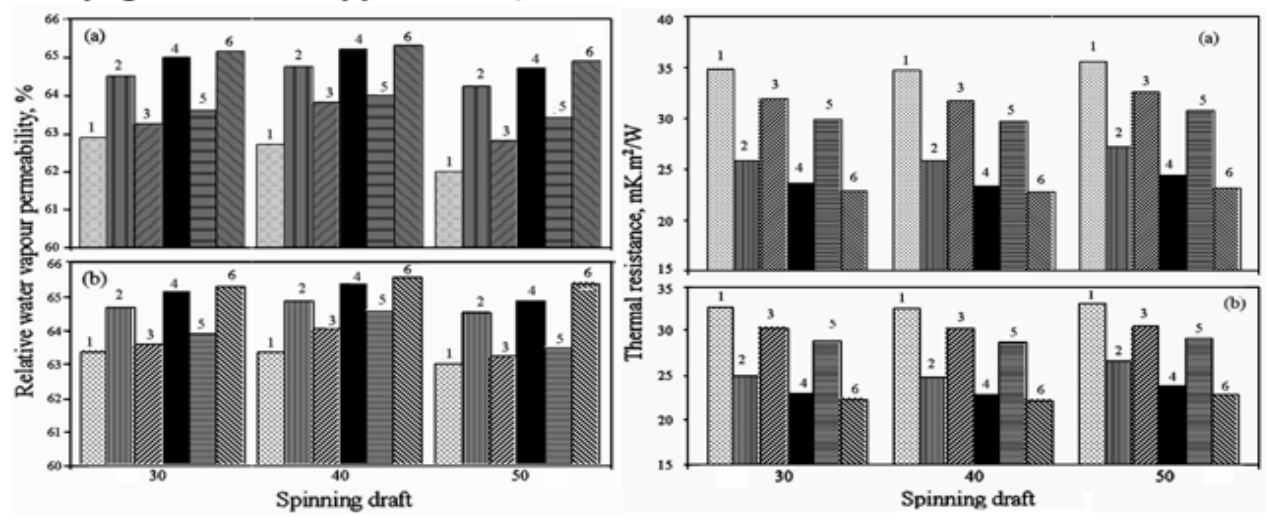

1,3,5 - Fabric Produced from Ring Yarn

2,4,6 - Fabric Produced from Compact Yarn

Figure 3. Relative water vapor permeability, and thermal resistance of compact fabric

(Tyagi, Bhattacharyya, 2010b)

Figure 3 shows that Relative Water Vapor Permeability is higher and thermal resistivity is lower for compact fabric in all three comparisons. Thermal resistance values are lower in compact fabrics when Relative Water Vapor Permeability (RWVP) values are higher due to its low hairiness, reduced yarn diameter, and increased porosity of the fabric (A. Das, 2007; Tyagi, Bhattacharyya, 2010b).

\section{Lower Fabric Thickness and Better Hand Feel}

The fabric manufactured with compact yarn is thinner (H. Zhang, and $\mathrm{X}$. Su, 2017). This is largely due to the compactness of the yarn, which reduces yarn diameter (Altas \& Kadoğlu, 2012; Dash, 2002; Ishtiaque, 2009; Yilmaz, 2007) and yarn hairiness (Altas \& Kadoğlu, 2012; Bijoya Kumar Behera, 2020; Divya, 2016; Elmogahzy, 2006; Eng, 2013; Haleem \& Wang, 2015; Hasan, 2016; Tyagi, Bhattacharyya, 2010a; Z. Xia, X. Wang, W. Ye, and W. $\mathrm{Xu}, 2015)$. Hairiness, unevenness ( U\%), thin place, thick place, and neps are all much lower in compact yarn, (Alsaid Ahmed Almetwally, 2015; Dash, 2002; H. A. Kim \& Kim, 2018; M. Krifa, E. Hequest, and D. Ethridge, 2002; Mamun, 2017; Murugan \& Shenmugam, 2021; Nikolić, 2003; Özgüney, 2008; P. Çelik, and H. Kadoğlu, 2004; Suzan, 2011; Uddin \& Jalil, 2015; Zou, 2011) resulting in a fabric with a better tactile feel. (Manonmani, 2010; Singh \& Nigam, 2013).

Because of its exceptional features, compact yarn is increasingly being used in a wide range of applications nowadays (Kane, 2007). Compact spinning is a modified version of ring spinning that provides a novel yarn structure; the advancement of compact spinning has set new yarn configuration benchmarks (Abou-Nassif, 2014). The application of core-spun 
yarns in fabric manufacturing and the clothing industry has grown dramatically. The spinning parameters have a major impact on market specifications, such as comfort behavior (A Das \& S M Ishtiaque, 2004; A. Das \& Chakraborty, 2014). The comfort behavior of any clothing has a substantial effect on the wearer's performance. As comfort is essential in the twenty-first century, using a compact spinning technology to produce cottonbased core-spun yarn can reduce hairiness, unevenness, and the imperfection index of the yarn, as well as improve thickness, air permeability, and MVPR, all of which will have a serious influence on the comfort properties of the enduse items manufactured from cotton-based core-spun yarn.

\section{Conclusion}

Cotton has no contender when it comes to comfort. Since cotton has better core coverage, it is possible to use a reasonable amount of special chemical finishes and adhesives, which are the main catalysts for aesthetics and comfort in fabrics. We can attain some favorable circumstances by using a compact spinning process in cotton-based core-spun yarn.

- Less hairiness, unevenness, and IPI (thick place, thin place, and neps of yarn) will be obtained in cotton-based compact core-spun fabric, ensuring soft and good hand feel, as well as low pilling and high abrasion resistance.

- Lower thickness, higher air permeability, lower thermal resistance, and higher Relative Water Vapor Permeability (RWVP) will contribute to a cooler fabric with good comfort characteristics, which can be produced utilizing cotton-based compact core-spun yarn.

- Cotton-based core-spun yarn will be low in hairiness, which will facilitate fabric production. Needles on knitting machines will be simpler, and less waste will be generated, leading to lower maintenance costs and increased machine longevity.

- Cotton-based core-spun yarn produced in compact spinning will ensure good comfort property alongside have higher production of yarn resulting in saving money, time, and energy.

\section{References:}

1. A Das \& S M Ishtiaque. (2004). Comfort Characteristics of Fabrics Containing Twist-less and Hollow Fibrous Assemblies in Weft A. 3(4), 1-7.

2. Abou-Nassif, G. A. (2014). A Comparative Study between Physical Properties of Compact and Ring Yarn Fabrics Produced from Medium and Coarser Yarn Counts. Journal of Textiles, 2014, 1-6. https://doi.org/10.1155/2014/569391

3. Adeli, B., Ghareaghaji, A. A., \& Shanbeh, M. (2011). Structural 
evaluation of elastic core-spun yarns and fabrics under tensile fatigue loading. Textile Research Journal, 81(2), 137-147. https://doi.org/10.1177/0040517510380104

4. Ahmad, M. M. (2009). Future spinning technology: Compact spinning. Pakistan Textile Journal, 58(2), 52-54.

5. Akankwasa, N. T., Wang, J., \& Zhang, Y. (2016). Study of optimum spinning parameters for production of T-400/cotton core spun yarn by ring spinning. Journal of the Textile Institute, 107(4), 504-511. https://doi.org/10.1080/00405000.2015.1045254

6. Akaydin, M. (2009). Characteristics of fabrics knitted with basic knitting structures from combed ring and compact yarns. Indian Journal of Fibre and Textile Research, 34(1), 26-30.

7. Akaydin, M., \& Can, Y. (2010). Pilling performance and abrasion characteristics of selected basic weft knitted fabrics. Fibres and Textiles in Eastern Europe, 79(2), 51-54.

8. Ali, N., \& Nassif, A. (2017). Thermal Comfort Properties of Compact and Ring Yarn Woven Fabrics. 30-36.

9. Almetwally, Alsaid A, \& Salem, M. M. (2010). Comparison Between Mechanical Properties Of Fabrics Woven From Compact And Ring Spun Yarns. 10(March), 35-40.

10. Almetwally, Alsaid Ahmed, Idrees, H. M. F., \& Hebeish, A. A. (2014). Predicting the tensile properties of cotton/spandex core-spun yarns using artificial neural network and linear regression models. Journal of the Textile Institute, 105(11), 1221-1229.

https://doi.org/10.1080/00405000.2014.882043

11. Almetwally, Alsaid Ahmed, Mourad, M. M., Hebeish, A. A., \& Ramadan, M. A. (2015). Comparison between physical properties of ring-spun yarn and compact yarns spun from different pneumatic compacting systems. 40(March), 43-50.

12. Altas, S., \& Kadoğlu, H. (2012). Comparison of conventional ring, mechanical compact and pneumatic compact yarn spinning systems. Journal of Engineered Fibers and Fabrics, 7(1), 87-100. https://doi.org/10.1177/155892501200700110

13. Babaarslan, O. (2001). Method of Producing a Polyester/Viscose Core-Spun Yarn Containing Spandex Using a Modified Ring Spinning Frame. Textile Research Journal, 71(4), 367-371.

14. Bar, M., Alagirusamy, R., \& Das, A. (2018). Properties of flaxpolypropylene composites made through hybrid yarn and film stacking methods. Composite Structures, 197, 63-71.

https://doi.org/10.1016/j.compstruct.2018.04.078

15. Barzoki, P. K., Vadood, M., \& Johari, M. S. (2017). Investigating the RoCos Core Spun Compact Yarn Properties. 5(2), 91-96. 
16. Basal, G., \& Oxenham, W. (2006). Comparison of Properties and Structures of Compact and Conventional Spun Yarns. Textile Research Journal, 76(7), 567-575.

https://doi.org/10.1177/0040517506065591

17. Beceren, Y., \& Nergis, B. U. (2008). Comparison of the Effects of Cotton Yarns Produced by New, Modified and Conventional Spinning Systems on Yarn and Knitted Fabric Performance. Textile Research Journal, 78(4), 297-303. https://doi.org/10.1177/0040517507084434

18. Bedez Ute, T. (2019). Analysis of mechanical and dimensional properties of the denim fabrics produced with double-core and corespun weft yarns with different weft densities. Journal of the Textile Institute, 110(2), 179-185.

https://doi.org/10.1080/00405000.2018.1470451

19. Behera, B. K., Ishtiaque, S. M., \& Chand, S. (1997). Comfort properties of fabrics woven from ring-, rotor-, and friction-spun yarns. Journal of the Textile Institute, 88(3), 255-264. https://doi.org/10.1080/00405009708658549

20. Behera, Bijoya Kumar. (2020). Comparative Studies on Ring, Compact and Vortex Yarns and Fabrics. Journal of Textile Science \& Fashion Technology, 6(5), 1-14.

https://doi.org/10.33552/jtsft.2020.06.000646

21. Bouhjar, F., Sahnoun, M., \& Cheikhrouhou, M. (2012). Study of the Theoretical and Rheological Models for the Mechanical Behaviour of Cotton Core Spun Yarn with Elastane. Journal of Textile Science \& Engineering, 02(02), 2-7. https://doi.org/10.4172/2165-8064.1000110

22. Chakraborty, A., \& Chatterjee, S. M. (1994). Influence of controlled pre-tension of core on hairiness of silk/nylon core-spun yarns. Indian Journal of Fibre \& Textile Research, 19(19), 12-16.

23. Chen, S. -A, \& Tsai, Y. -C. (1989). Electrochemical polymerization of pyrrole on a fabric. Die Angewandte Makromolekulare Chemie, 169(1), 153-157. https://doi.org/10.1002/apmc.1989.051690114

24. Choi, K. F., \& Kim, K. L. (2004). Fiber Segment Length Distribution on the Yarn Surface in Relation to Yarn Abrasion Resistance. Textile Research Journal, 74(7), 607-610. https://doi.org/10.1177/004051750407400709

25. Dang, M., Wang, S., \& Liu, G. (2008). Theoretical prediction on tensile model of wool/spandex core-spun yarn. Journal of Industrial Textiles, 37(4), 301-313. https://doi.org/10.1177/1528083707083792

26. Das, A., \& Chakraborty, R. (2014). Studies on elastane-cotton corespun stretch yarns and fabrics: Part III-Comfort characteristics. Indian Journal of Fibre and Textile Research, 39(3), 282-288.

27. Das, A., Ishtiaque, S. M., \& Yadav, P. (2004). Contribution of Core 
and Sheath Components to the Tensile Properties of DREF-III Yarn. Textile Research Journal, 74(2), 134-139. https://doi.org/10.1177/004051750407400209

28. Das, A., Kothari, V. K., \& Sadachar, A. (2007). Comfort characteristics of fabrics made of compact yarns. Fibers and Polymers, 8(1), 116-122. https://doi.org/10.1007/BF02908169

29. Das, B., Das, A., Kothari, V., Fanguiero, R., \& Araujo, M. D. (2009). Moisture flow through blended fabrics - Effect of hydrophilicity. Journal of Engineered Fibers and Fabrics, 4(4), 20-28. https://doi.org/10.1177/155892500900400405

30. Das, B., Das, A., Kothari, V. K., Fangueiro, R., \& Araújo, M. De. (2007). Part II : Evaluation Methods and Mathematical Modelling. Autex Research Journal, 7(September), 194-216.

31. Dash, J. R., Ishtiaque, S. M., \& Alagirusamy, R. (2002). Properties and processibility of compact yarns. Indian Journal of Fibre and Textile Research, 27(4), 362-368.

32. Divya, R., Manonmani, G., \& Jayakumari, M. (2016). Comparative study on ring spun yarn and compact spun yarn. 2(2), 374-384.

33. Doran, E. C., \& Sahin, C. (2020). The prediction of quality characteristics of cotton/elastane core yarn using artificial neural networks and support vector machines. Textile Research Journal, 90(13-14), 1558-1580. https://doi.org/10.1177/0040517519896761

34. du, Z., Zhou, M., he, L., \& Liu, H. (2015). Study on negative Poisson's ratio of auxetic yarn under tension: Part 2 - Experimental verification. Textile Research Journal, 85(7), 768-774. https://doi.org/10.1177/0040517514549987

35. El-Sayed, M. A. M., \& Sanad, S. H. (2007). The Impact of New Spinning Technologies on the. AUTEX Research Journal, 8(4), 231238.

36. El-Sayed, M. A. M., \& Sanad, S. H. (2010). Compact spinning technology. Advances in Yarn Spinning Technology, 237-260. https://doi.org/10.1533/9780857090218.2.237

37. Elite, S., \& Gmbh, S. S. (2019). Comparative analysis of yarn properties produced on pneumatic. mm, 179-181.

38. Elmogahzy, Y. (2006). Yarn engineering. 31(March), 150-159.

39. Eng, J. T. S., Sb, A., \& Sandip, J. (2013). Journal of Textile Science \& Engineering Properties Evaluation of Cotton Ring and Compact Spun Yarns after Scouring and Bleaching Process. 3(3), 3-5.

https://doi.org/10.4172/2165-8064.1000139

40. Erez, E., \& Çelik, P. (2014). a Research on the Parameters of the Affecting Yarn Properties of Cotton-Polyester Rigid Core-Spun Yarns PamukPoliester Sert ÖzlEğrilmiİplikleriİpliÖzellikleriniEtkileyen 
ParametrelerÜzerineBir Araştirma. TEKSTİL ve KONFEKSIYON, 1 , 195-201. https://dergipark.org.tr/download/article-file/218230

41. Ertaş, O. G., Zervent Ünal, B., \& Çelik, N. (2016). Analyzing the effect of the elastane-containing dual-core weft yarn density on the denim fabric performance properties. Journal of the Textile Institute, 107(1), 116-126. https://doi.org/10.1080/00405000.2015.1016319

42. F. Göktepe, D. Yilmaz, and Ö. Göktepe. (2015). A Comparison of Compact Yarn Properties Produced on Different Systems Material and Methods. 76(3), 226-234. https://doi.org/10.1177/0040517506061241

43. Ferreira, M., Bourbigot, S., Flambard, X., \& Vermeulen, B. (2004). Interest of a compound yarn to improve fabric performance. Autex Research Journal, 4(1), 14-18.

44. Fu, T., Zhang, Y., Akankwasa, N. T., Chen, N., \& Lin, H. (2021). Study on the model of semi-open-end twist in compact spinning with lattice apron. Textile Research Journal, 91(5-6), 467-479. https://doi.org/10.1177/0040517520942545

45. G. Manonmani, C. Vigneswaran, K. Chandrasekaran, and T. Ramachandran. (2013). Effect of Ring and Compact Cotton Spun Yarn characteristics on Physical and Comfort Properties of Knitted Fabrics. RJTA, 17(3), 68-82.

46. Gazi Ortlek, H., \& Ulku, S. (2007). Effects of Spandex and Yarn Counts on the Properties of Elastic Core-spun Yarns Produced on Murata Vortex Spinner. Textile Research Journal, 77(6), 432-436. https://doi.org/10.1177/0040517507078022

47. Gharehaghaji, A. A., Shanbeh, M., \& Palhang, M. (2007). Analysis of Two Modeling Methodologies for Predicting the Tensile Properties of Cotton-covered Nylon Core Yarns. Textile Research Journal, 77(8), 565-571. https://doi.org/10.1177/0040517507078061

48. Gokarneshan, N. (2005). An investigation on the minimum twist of cohesion of ring and compact spun yarns. 30, 340-343.

49. Gokarneshan, N., \& Thangamani, K. (2010). An investigation into the properties of cotton/spandex and polyester/spandex knitted fabrics. Journal of the Textile Institute, 101(2), 182-186.

https://doi.org/10.1080/00405000802332032

50. Gorjanc, D. S., \& Bizjak, M. (2014). The influence of constructional parameters on deformability of elastic cotton fabrics. Journal of Engineered Fibers and Fabrics, 9(1), 38-46. https://doi.org/10.1177/155892501400900106

51. H. Zhang, and X. Su. (2017). Comparative analysis on pneumatic compact spinning systems. The Eletronic Library, 34(1), 1-5.

52. H, H. (2013). Rheological Modeling of the Dorlastan Core Spun Yarns for Various Dorlastan Drafts and Yarn Counts. Journal of Textile 
Science \& Engineering, 03(01). https://doi.org/10.4172/21658064.1000127

53. Haleem, N., \& Wang, X. (2015). Recent research and developments on yarn hairiness. https://doi.org/10.1177/0040517514538692

54. Harper, R. J., Ruppenicker, G., \& Donaldson, D. (1986). Cotton Blend Fabrics from Polyester Core Yarns. Textile Research Journal, 56(2), 80-86. https://doi.org/10.1177/004051758605600202

55. Harper, R. J., \& Ruppenicker, G. F. (1987). Woven Fabrics Prepared from High Tenacity Cotton/Polyester Core Yarn. Textile Research Journal, 57(3), 147-154. https://doi.org/10.1177/004051758705700304

56. Hasan, K. M. F. (2016). Potentiality of Compact Yarn in Knit Dyeing for Cleaner Production. International Journal Of Scientific \& Engineering Research, 7(7), 1033-1037.

57. Helali, H., Babay, A. D., \& Msahli, S. (2012). Effect of elastane draft on the rheological modelling of elastane core spun yarn. Journal of the Textile Institute, 103(4), 451-457.

https://doi.org/10.1080/00405000.2011.584383

58. Helali, H., Babay Dhouib, A., Msahli, S., \& Cheikhrouhou, M. (2012). Influence of Dorlastan ${ }^{\circledR}$ draft and yarn count on the elastic recovery of the Dorlastan ${ }^{\circledR}$ core spun yarns following cyclic test. Journal of the Textile Institute, 103(4), 378-384.

https://doi.org/10.1080/00405000.2011.580542

59. Helali, Houda, Babay Dhouib, A., Msahli, S., \& Cheikhrouhou, M. (2013). Study of Specific conditions to control the mechanical behaviour of Dorlastan ${ }^{\circledR}$ core spun yarn. Fibres and Textiles in Eastern Europe, 99(3), 55-60.

60. Herath, C. N., \& Kang, B. C. (2008). Dimensional Stability of Core Spun Cotton/Spandex Single Jersey Fabrics under Relaxation. Textile Research Journal, 78(3), 209-216. https://doi.org/10.1177/0040517507082958

61. Hoeft, L. O., \& Tokarsky, E. W. (2000). Measured electromagnetic shielding characteristics of fabric made from metal clad aramid yarn and wire. IEEE International Symposium on Electromagnetic Compatibility, 2, 883-886. https://doi.org/10.1109/isemc.2000.874739

62. Hua, T., Wong, N. S., \& Tang, W. M. (2018). Study on properties of elastic core-spun yarns containing a mix of spandex and PET/PTT bicomponent filament as core. Textile Research Journal, 88(9), 10651076. https://doi.org/10.1177/0040517517693982

63. Hyun, K. S., Spalding, M. A., \& Hinton, C. E. (1997). Theoretical and experimental analysis of solids conveying in single-screw extruders. 
Journal of Reinforced Plastics and Composites, 16(13), 1210-1219. https://doi.org/10.1177/073168449701601305

64. Ishtiaque, S. M., Subramani, P., Kumar, A., \& Das, B. R. (2009). Structural and tensile properties of ring and compact plied yarns. 34(September), 213-218.

65. Jabbar, A., Tariq, U., Hussain, T., Basit, A., Hai, A. M., \& Zubair, M. (2020). Effect of polyester and elastane linear density on the physical and mechanical properties of dual-core-spun cotton yarns. Journal of Natural Fibers, 17(4), 463-471. https://doi.org/10.1080/15440478.2018.1500338

66. Jackowski, T., \& Cyniak, D. (2004). Compact Cotton Yarn. 12(4), 22 26.

67. Jaouachi, B., Moussa, A., Ben Hassen, M., \& Sakli, F. (2011). Image analysis of the elastane position effect on the appearance of wet pneumatic spliced elastic core-spun yarn. Textile Research Journal, 81(14), 1460-1469. https://doi.org/10.1177/0040517511398948

68. Javazmi, L., Ravandi, S. A. H., \& Ghareaghaji, A. A. (2014). Fabrication and characterization of PET nanofiber hollow yarn. Fibers and Polymers, 15(5), 954-960. https://doi.org/10.1007/s12221-0140954-9

69. Jeddi, A. A. A., Johari, M. S., \& Merati, A. A. (1997). A study of the structural and physical properties of cotton-covered nylon filament core-spun yarns. Journal of the Textile Institute, 88(1), 12-20. https://doi.org/10.1080/00405009708658525

70. Jiang, X., Wang, Q., Cheng, L., \& Yu, J. (2012). Comparison of the properties of akund / cotton blended yarn produced by compact spinning with pure cotton yarn. 219, 590-593. https://doi.org/10.4028/www.scientific.net/AMM.217-219.590

71. Józkowicz, I., \& Drobina, R. (2010). Comparative Analysis of Ring Spinning for Both Classic and Compact Yarns . Part II : Verification of Models Created. 18(5), 28-34.

72. Kadoğlu, H., Dimitrovski, K., Marmarali, A., Çelik, P., Bayraktar, G. B., Üte, T. B., Ertekin, G., Demšar, A., \& Kostanjek, K. (2016). Investigation of the characteristics of elasticised woven fabric by using PBT filament yarns. Autex Research Journal, 16(2), 109-117. https://doi.org/10.1515/aut-2015-0025

73. Kakvan, A., Shaikhzadeh Najar, S., Ghazi Saidi, R., \& Nami, M. (2007). Effects of draw ratio and elastic core yarn positioning on physical properties of elastic wool/polyester core-spun ring yarns. Journal of the Textile Institute, 98(1), 57-63. https://doi.org/10.1533/joti.2005.0194

74. Kane, C. D., Patil, U. J., \& Sudhakar, P. (2007). Studies on the 
Influence of Knit Structure and Stitch Length on Ring and Compact Yarn Single Jersey Fabric Properties. Textile Research Journal, 77(8), 572-582. https://doi.org/10.1177/0040517507078023

75. Kawabata, S., \& Niwa, M. (1989). Fabric performance in clothing and clothing manufacture. Journal of the Textile Institute, 80(1), 19-50. https://doi.org/10.1080/00405008908659184

76. Kawabata, S., \& Niwa, M. (1991). Objective Measurement of Fabric Mechanical Property and Quality: International Journal of Clothing Science and Technology, 3(1), 7-18.

https://doi.org/10.1108/eb002968

77. Kaynak, H. K. (2017). Optimization of stretch and recovery properties of woven stretch fabrics. Textile Research Journal, 87(5), 582-592. https://doi.org/10.1177/0040517516632480

78. Kim, H. A., \& Kim, S. J. (2018). Mechanical Properties of Micro Modal Air Vortex Yarns and the Tactile Wear Comfort of Knitted Fabrics. 19(1), 211-218. https://doi.org/10.1007/s12221-018-7690-x

79. Kim, H. J., Kim, J. S., Lim, J. H., \& Huh, Y. (2009). Detection of Wrapping Defects by a Machine Vision and its Application to Evaluate the Wrapping Quality of the Ring Core Spun Yarn. Textile Research Journal, 79(17), 1616-1624.

https://doi.org/10.1177/0040517509103509

80. Kim, H. J., Yang, H. W., Zhu, C. Y., \& Huh, Y. (2009). Influence of the core-sheath weight ratio and twist on the tensile strength of the ring core yarns with high tenacity filaments. Fibers and Polymers, 10(4), 546-550. https://doi.org/10.1007/s12221-009-0546-2

81. Krifa, M., \& Ethridge, M. D. (2006). Compact Spinning Effect on Cotton Yarn Quality: Interactions with Fiber Characteristics. 76(5), 388-399. https://doi.org/10.1177/0040517506062648

82. Kumar, B., Dasa, A., \& Singh, P. A. (2014). Studies on elastane-cotton core-spun stretch yarns and fabrics: Part III - Comfort characteristics. Indian Journal of Fibre and Textile Research, 39(3), 282-288.

83. Liu, X., Su, X., \& Song, J. (2019). Research on yarn qualities modified by mechanical false-twisting device. The Journal of The Textile Institute, 0(0), 1-11. https://doi.org/10.1080/00405000.2019.1649581

84. Loganathan, R., Mallyah, M., \& Ramachandran, T. (n.d.). Influence of D - Type Slot Compact System on Migration Properties of the Carded Compact Yarn. 7-13.

85. Lou, C. W. (2005). Process of Complex Core Spun Yarn Containing a Metal Wire. Textile Research Journal, 75(6), 466-473.

https://doi.org/10.1177/0040517505053871

86. M. A. Shahid, M. D. Hossain, M. N. U. Hasan, and M. A. Islam. (2014). Comparative Study of Ring and Compact Yarn-Based Knitted 
Fabric. ICME 2013, 90, 154-159. https://doi.org/10.1016/j.proeng.2014.11.829

87. M. Krifa, E. Hequest, and D. Ethridge. (2002). COMPACT SPINNING: NEW POTENTIAL FOR SHORT STAPLE COTTONS. Spring 2002*, 2002(2).

88. Ma, H., Cheng, L., Yan, G., \& Xu, S. (2012). Influence of Technological Parameter for Ramie Yarn Hairiness on Compact Spinning with Suction Groove. 219, 1695-1698. https://doi.org/10.4028/www.scientific.net/AMM.217-219.1695

89. Mamun, R. Al, Repon, M. R., Jalil, M. A., \& Uddin, A. J. (2017). Comparative Study on Card Yarn Properties Produced from Conventional Ring and Compact Spinning. Universal Journal of Engineering Science, 5(1), 5-10. https://doi.org/10.13189/ujes.2017.050102

90. Manonmani, G., Chettiar, V., \& Ramachandran, T. (2010). Suitability of compact yarn for manufacturing of eco-friendly processed weft knitted fabrics. Journal of Textile and Apparel, Technology and Management, 6(3), 1-18.

91. Matsumoto, Y., Tsuchiya, I., Toriumi, K., \& Harakawa, K. (1990). A study of throstle-spun-silk/raw-silk core-spun yarn part I: Yarn properties. Journal of the Textile Institute, 81(1), 48-58. https://doi.org/10.1080/00405009008658325

92. Merati, A. A., Konda, F., Okamura, M., \& Marui, E. (1998). Filament Pre-tension in Core Yarn Friction Spinning. Textile Research Journal, 68(4), 254-264. https://doi.org/10.1177/004051759806800403

93. Merati, A. A., Najar, S. S., Etrati, S. M., \& Goodarzi, M. (2012). Effect of spandex filament draw ratio on elastic core spun yarn properties in friction spinning. Textile Research Journal, 82(13), 1363-1370. https://doi.org/10.1177/0040517512439920

94. Merati, A. A., \& Okamura, M. (2001). Hollow Yarn in Friction Spinning. Part II: Yarn Structure and Deformation Under Axial Tension and Lateral Forces. Textile Research Journal, 71(5), 454-458. https://doi.org/10.1177/004051750107100514

95. Merati, A. A., \& Okamura, M. (2003). Limits of Hollow Yarn in Friction Spinning. Textile Research Journal, 73(6), 496-502. https://doi.org/10.1177/004051750307300606

96. Messiry, M. El, Hosny, N., \& Esmat, G. (2013). Optimization of the combing noil percentage for quality single and ply compact spun yarn. Alexandria Engineering Journal, 52(3), 307-311. https://doi.org/10.1016/j.aej.2013.01.004

97. Miao, M., Barnes, S., \& Vuckovic, L. (2010). High-speed video graphic study of filament-core yarn spinning. Journal of the Textile 
Institute, 101(3), 242-252.

https://doi.org/10.1080/00405000802376179

98. Miao, Menghe, How, Y. L., \& ho, S. Y. (1996). Influence of Spinning Parameters on Core Yarn Sheath Slippage and Other Properties. Textile Research Journal, 66(11), 676-684. https://doi.org/10.1177/004051759606601102

99. Murugan, K., \& Shenmugam, V. (2021). Optimization of Cotton Compact Yarn Product by Fibre Properties. 4(5), 96-103.

100. Naeem, M. A., Akankwasa, N. T., Leroy, A., Siddiqui, Q., \& Ahmad, A. (2019). A study of novel multifilament spreading and feeding method, to produce filament wrapped-staple core composite yarn using modified ring frame. Journal of the Textile Institute, 110(3), 378-385. https://doi.org/10.1080/00405000.2018.1480342

101.Nikolić, M., Stjepanovič, Z., Lesjak, F., \& Štritof, A. (2003). Compact spinning for improved quality of ring-spun yarns. Fibres and Textiles in Eastern Europe, 11(4), 30-35.

102. Oğulata, R. T. (2007). The effect of thermal insulation of clothing on human thermal comfort. Fibres and Textiles in Eastern Europe, 15(2), $67-72$.

103. Omeroglu, S., \& Ulku, S. (2007). An investigation about tensile strength, piling and abrasion properties of woven fabrics made from conventional and compact ring-spun yarns. Fibres and Textiles in Eastern Europe, 15(1), 39-42.

104. Oparin, M. L., Oparina, O. S., \& Matrosov, A. N. (2010). Динамика Фауны Млекопитающих Степей Волго - Уральского Междуречья За Последнее Столетие М . Л . Опарин 1 , О . С . Опарина 1, А . Н . Матросов 2 , А . А . Кузнецов 2. 486(082), 71-85.

105. Özdil, N., Özdoğan, E., \& Demirel, A. (2005). A Comparative Study of the Characteristics of Compact Yarn-Based Knitted Fabrics. 13(2), 39-43.

106. Özgüney, A. T., Dönmez Kretzschmar, S., Özçelik, G., \& Özerdem, A. (2008). The Comparison of Cotton Knitted Fabric Properties Made of Compact and Conventional Ring Yarns Before and After the Printing Process. Textile Research Journal, 78(2), 138-147. https://doi.org/10.1177/0040517507080249

107. Ozturk, M., \& Nergis, B. U. (2008). Determining the dependence of colour values on yarn structure. 87, 145-150. https://doi.org/10.1111/j.1478-4408.2008.00134.x

108. P. Çelik, and H. Kadoğlu. (2004). A Research on the Compact Spinning for Long Staple Yarns. 12(4), 27-31.

109. Perumalraj, R., \& Dasaradan, B. S. (2009). Electromagnetic shielding effectiveness of copper core yarn knitted fabrics. Indian Journal of 
Fibre and Textile Research, 34(2), 149-154.

110. Perumalraj, R., \& Dasaradan, B. S. (2010). Tensile properties of copper core yarn. Journal of Reinforced Plastics and Composites, 29(11), 1688-1701. https://doi.org/10.1177/0731684409341676

111. Perumalraj, R., Dasaradan, B. S., Anbarasu, R., Arokiaraj, P., \& Leo Harish, S. (2009). Electromagnetic shielding effectiveness of copper core-woven fabrics. Journal of the Textile Institute, 100(6), 512-524. https://doi.org/10.1080/00405000801997587

112. Pourahmad, A., \& Johari, M. S. (2009). Production of core-spun yarn by the three-strand modified method. Journal of the Textile Institute, 100(3), 275-281. https://doi.org/10.1080/00405000701763865

113. Pramanik, P., \& Patil, V. M. (2009). Physical characteristics of cotton/polyester core spun yarn made using ring and air-jet systems. Autex Research Journal, 9(1), 14-19.

114. Qadir, B., Hussain, T., \& Malik, M. (2014). Effect of elastane denier and draft ratio of core-spun cotton weft yarns on the mechanical properties of woven fabrics. Journal of Engineered Fibers and Fabrics, 9(1), 23-31. https://doi.org/10.1177/155892501400900104

115. Qadir, M. B., Ali, Z., Afzal, A., Irfan, M., Hussain, T., Malik, M. H., Iqbal, M. W., Shahzad, A., Ahmad, A., \& Khaliq, Z. (2020). Effect of Elastane Parameters on the Dimensional and Mechanical Properties of Stretchable Denim Fabrics. Clothing and Textiles Research Journal, 115. https://doi.org/10.1177/0887302X20968812

116. Radhakrishnaiah, P., \& Sawhney, A. P. S. (1996). Low Stress Mechanical Behavior of Cotton / Polyester Yarns and Fabrics in Relation to Fiber Distribution Within the Yarn. Textile Research Journal, 66(2), 99-103. https://doi.org/10.1177/004051759606600206

117. Radhakrishnaiah, P., Tejatanalert, S., \& Sawhney, A. P. S. (1993). Handle and Comfort Properties of Woven Fabrics Made from Random Blend and Cotton-Covered Cotton/Polyester Yarns. Textile Research Journal, 63(10), 573-579.

https://doi.org/10.1177/004051759306301003

118. Raj, S., \& Sreenivasan, S. (2009). Total wear comfort index as an objective parameter for characterization of overall wearability of cotton fabrics. Journal of Engineered Fibers and Fabrics, 4(4), 29-41. https://doi.org/10.1177/155892500900400406

119. Raja, D., Kouhik, C. V, Ramakrishnan, G., Babu, V. R., \& Subramaniam, V. (2012). Horizontal liquid spreading behaviour of hybrid yarn woven fabric using embedded image analysis principle. 37(December), 381-384.

120. Ramachandran, T., \& Vigneswaran, C. (2009). Design and development of copper core conductive fabrics for smart textiles. 
Journal of Industrial Textiles, 39(1), 81-93. https://doi.org/10.1177/1528083709103317

121. Ramakrishnan, G. (2006). Fibre migration in compact-spun yarn s : Part I-Pneumatic compact yarn. 3(September).

122. Ramkumar, S. S., Leaf, G. A. V., \& Harlock, S. C. (2000). A Study of the Frictional Properties of $1 \times 1$ Rib-knitted Cotton Fabrics. Journal of the Textile Institute, 91(3), 374-382. https://doi.org/10.1080/00405000008659514

123. Realff, M. L. (2015). Objective Subjective Analysis of Knitted Fabric. 977-982.

124. Regar, M. L., Amjad, A. I., \& Aikat, N. (2017). Studies On The Properties Of Ring. 2, 476-483.

125.Ruppenicker, G. F., Harper, R. J., Sawhney, A. P., \& Robert, K. Q. (1989). Comparison of Cotton/Polyester Core and Staple Blend Yarns and Fabrics. Textile Research Journal, 59(1), 12-17. https://doi.org/10.1177/004051758905900102

126. Sarığlu, E., \& Babaarslan, O. (2017). A comparative strength analysis of denim fabrics made from core-spun yarns containing textured microfilaments. Journal of Engineered Fibers and Fabrics, 12(1), 2232. https://doi.org/10.1177/155892501701200103

127. Sawhney, A. P. S., Harper, R. J., Robert, K. Q., \& Ruppenicker, G. F. (1991). Finishing and Properties of Fabrics Produced with Polyester Staple-Core/Cotton-Wrap Yams. Textile Research Journal, 61(7), 393-397. https://doi.org/10.1177/004051759106100705

128. Sawhney, A. P. S., Harper, R. J., Ruppenicker, G. F., \& Robert, K. Q. (1991). Comparison of Fabrics Made with Cotton Covered Polyester Staple-Core Yarn and 100\% Cotton Yarn. Textile Research Journal, 61(2), 71-74. https://doi.org/10.1177/004051759106100202

129. Sawhney, A. P. S., Robert, K. Q., \& Ruppenicker, G. F. (1989). Device for Producing Staple-Core / Cotton-Wrap Ring Spun Yarns. Textile Research Journal, 59(9), 519-524.

https://doi.org/10.1177/004051758905900905

130. Sawhney, A. P. S., Robert, K. Q., Ruppenicker, G. F., \& Kimmel, L. B. (1992). Improved Method of Producing a Cotton Covered/Polyester Staple-Core Yarn on a Ring Spinning Frame. Textile Research Journal, 62(1), 21-25. https://doi.org/10.1177/004051759206200104

131.Sawhney, A. P. S., \& Ruppenicker, G. F. (1997). Special purpose fabrics made with core-spun yarns. Indian Journal of Fibre and Textile Research, 22(4), 246-254.

132. Sawhney, A. P. S., Ruppenicker, G. F., Kimmel, L. B., \& Robert, K. Q. (1992). Comparison of Filament-Core Spun Yarns Produced by New and Conventional Methods. Textile Research Journal, 62(2), 67- 
73. https://doi.org/10.1177/004051759206200202

133. Şengöz, N. G. (2004). Bagging in textiles. Textile Progress, 36(1), $37-$ 41. https://doi.org/10.1533/jotp.36.1.1.59475

134. Shanbeh, M., Baghaei, B., Alidadi, S., \& Tabibi, A. (2011). Coating of core yarn. An alternative method of decreasing the strip-back phenomenon of core-spun yarns. Fibres and Textiles in Eastern Europe, 88(5), 28-32.

135.Singh, M. K., \& Nigam, A. (2013). Effect of Various Ring Yarns on Fabric Comfort. 2013, 1-8.

136.Sinha, S. K., Bansal, P., \& Maity, S. (2017). Tensile and Elastic Performance of Cotton/Lycra Core Spun Denim Yarn. Journal of The Institution of Engineers (India): Series E, 98(1), 71-78. https://doi.org/10.1007/s40034-017-0095-y

137. Sitotaw, D. B. (2018). Dimensional Characteristics of Knitted Fabrics Made from 100\% Cotton and Cotton/Elastane Yarns. Journal of Engineering (United Kingdom), 2018. https://doi.org/10.1155/2018/8784692

138. Sowrov, K., \& Ahmed, P. M. (2014). An investigation on the variation of woven fabric properties made from regular ring spun , compact \& SIRO spun yarn . 88-91.

139.su, C. I., Fang, J. X., Chen, X. H., \& wu, W. Y. (2007). Moisture Absorption and Release of Profiled Polyester and Cotton Composite Knitted Fabrics. Textile Research Journal, 77(10), 764-769. https://doi.org/10.1177/0040517507080696

140.Su, X., Su, X., \& Liu, X. (2020). Research on performance of twincore spun yarn and fabric. International Journal of Clothing Science and Technology, 32(3), 338-355. https://doi.org/10.1108/IJCST-122018-0162

141.Sun, J., Huang, Y., Fu, C., Wang, Z., Huang, Y., Zhu, M., Zhi, C., \& $\mathrm{Hu}, \mathrm{H}$. (2016). High-performance stretchable yarn supercapacitor based on PPy@CNTs@urethane elastic fiber core spun yarn. Nano Energy, 27, 230-237. https://doi.org/10.1016/j.nanoen.2016.07.008

142. Suzan, H. (2011). Production Of Carded Compact Cotton Yarn Of Comparable Quality To The Combed Conventional. 89(1), 203-212.

143. T. N. Shaikh, R. Radadiya, and A. Rawal. (2017). Compact Yarn as a Replacement of Doubled Yarn in Apparel Fabric-an Analytical Snap. 1(5), 1-7. https://doi.org/10.15406/jteft.2017.01.00033

144.T. Siddiqua, M. A. Reza, and H. Altaf. (2019). Statistical Analysis of Properties of Compact Yarn Produced from Different Process. European Scientific Journal ESJ, 15(12), 150-158. https://doi.org/10.19044/esj.2019.v15n12p150

145. Taylor, P., Liu, X., Liu, W., Zhang, H., \& Su, X. (2014). The Journal 
of The Textile Institute Research on pneumatic compact spun yarn quality. October, 37-41.

https://doi.org/10.1080/00405000.2014.925198

146. Taylor, P., Mavruz, S., \& Ogulata, R. T. (2011). The Journal of The Textile Institute Investigation of air permeability of single jersey fabrics with different relaxation states. October 2014, 37-41. https://doi.org/10.1080/00405000903474907

147.Taylor, P., Raja, D., Prakash, C., Gunasekaran, G., \& Koushik, C. V. (2014). The Journal of The Textile Institute A study on thermal properties of single-jersey knitted fabrics produced from ring and compact folded yarns. January 2015, 37-41.

https://doi.org/10.1080/00405000.2014.912783

148. Taylor, P., Soltani, P., \& Johari, M. S. (2012). A study on siro- , solo, compact- , and conventional ring-spun yarns . Part II : yarn strength with relation to physical and structural properties of yarns. December 2013, 37-41. https://doi.org/10.1080/00405000.2011.628117

149.Tyagi, G. K., Bhattacharyya, S., Bhowmick, M., \& Narang, R. (2010a). Study of cotton ring- And compact-spun yarn fabrics: Part II - Effects of spinning variables on comfort characteristics. Indian Journal of Fibre and Textile Research, 35(2), 128-133.

150.Tyagi, G. K., Bhattacharyya, S., Bhowmick, M., \& Narang, R. (2010b). Study of cotton ring-and compact-spun yarn fabrics: Part i Effects of spinning variables on hand-related characteristics. Indian Journal of Fibre and Textile Research, 35(1), 45-49.

151. Tyagi, G. K., Bhowmick, M., Bhattacharyya, S., \& Kumar, R. (2010). Effect of spinning conditions on mechanical and performance characteristics of cotton ring- And compact-spun yarns. Indian Journal of Fibre and Textile Research, 35(1), 21-30.

152.Uddin, N., \& Jalil, M. A. (2015). Retrofitting Of Simple Mechanical Compacting Device ( Rocos ) On Conventional Ring Spinning Machine For Improving Yarn Quality. 11(3), 68-74.

153.Wan, A., Yu, W., \& Jiang, G. (2014). Textile Research Journal. https://doi.org/10.1177/0040517513509854

154.Wang, Z., Huang, Y., Sun, J., Huang, Y., Hu, H., Jiang, R., Gai, W., Li, G., \& Zhi, C. (2016). Polyurethane/Cotton/Carbon Nanotubes Core-Spun Yarn as High Reliability Stretchable Strain Sensor for Human Motion Detection. ACS Applied Materials and Interfaces, 8(37), 24837-24843. https://doi.org/10.1021/acsami.6b08207

155.Wu, H., Chen, M., \& Wang, W. (2009). The Structure of Compact Yarn Configuration of Fibers within Yarns Analysis of Structure of Two Cotton Yarns. 79(9), 810-814.

https://doi.org/10.1177/0040517508097513 
156. Yang, H. W., Kim, H. J., Zhu, C. Y., \& Huh, Y. (2009). Comparisons of Core-Sheath Structuring Effects on the Tensile Properties of HighTenacity Ring Core-Spun Yarns. Textile Research Journal, 79(5), 453-460. https://doi.org/10.1177/0040517508099912

157. Yanhong, W., Liu, X., Su, X., \& Zhimin, Z. (2019). Effects of spinning process and core yarn contents on yarn shape retention. International Journal of Clothing Science and Technology, 32(4), 457-469. https://doi.org/10.1108/IJCST-11-2018-0142

158. Yilmaz, D. (2013). Investigation of Yarn Properties of Modified Yarn Spinning Systems with Air Nozzle Attachment. 2(98), 43-50.

159. Yilmaz, D., Göktepe, F., Göktepe, Ö., \& Kremenakova, D. (2007). Packing Density of Compact Yarns. Textile Research Journal, 77(9), 661-667. https://doi.org/10.1177/0040517507078796

160. Yoon, H. N., Sawyer, L. C., \& Buckley, A. (1984). Improved Comfort Polyester: Part II: Mechanical and Surface Properties. Textile Research Journal, 54(6), 357-365. https://doi.org/10.1177/004051758405400601

161. Yu, A., Pu, X., Wen, R., Liu, M., Zhou, T., Zhang, K., Zhang, Y., Zhai, J., Hu, W., \& Wang, Z. L. (2017). Core-Shell-Yarn-Based Triboelectric Nanogenerator Textiles as Power Cloths. ACS Nano, 11(12), 12764-12771. https://doi.org/10.1021/acsnano.7b07534

162. Yuan, L., Fan, W., Miao, Y., Li, J., Xue, L., Dang, W., Dong, J., Wei, L., \& Sun, R. (2019). Enhanced mechanical and electromagnetic properties of polymer composite with 2.5D novel carbon/quartz fiber core-spun yarn woven fabric. Journal of Industrial Textiles, 1-18. https://doi.org/10.1177/1528083719866937

163.Z. Xia, X. Wang, W. Ye, and W. Xu. (2015). Experimental Investigation on the Effect of Singeing on Cotton Yarn Properties. 79(17), 1610-1615. https://doi.org/10.1177/0040517508099389

164.Zaidi, N. I., Ali, M. T., Rahman, N. H. A., Amin, M. S., Shah, A. A. S. A., \& Yahya, M. F. (2018). Comparison of Copper Covered and Copper Core Sheath Yarn for the Fabrication of Textile Antenna. IEESR Journal, 13.

165.Zou, Z., Guo, Y., Zheng, S., Cheng, L., \& Liu, S. (2011). Model of the Yarn Twist Propagation in Compact Spinning with a Pneumatic Groove. 19(1), 30-33. 